\title{
Nimensä mukaisesti irtiotto
}

\section{Raimo Mäkinen \& Olli Poropudas (toim. 2001). Irtiotto 90-Iuvun koulutuspolitiikasta. 212 s. Turun yliopiston kasvatustieteiden tie- dekunnan julkaisuja B:67.}

\section{Kirjan Irtiotto 90-Iuvun}

koulutuspolitiikasta alaotsikko määrittelee teoksen koulutuspoliittiseksi artikkelikokoelmaksi. Teos alkaa oikeaoppisesti toimittajien johdantoartikkelilla 1990-luvun koulutuspolitiikan taustoista ja yleispiirteistä, ja se päättyy toimittajien kokoavaan artikkeliin koulutuspolitiikan akuuteista ongelmista, joiden ratkaisemiseksi he esittävät kymmenen kohdan toimenpideohjelman. Loput yhdeksän artikkelia käsittelevät kansainvälistä yhteistyötä koulutuspolitiikassa, koulutusmarkkinoita, toisen asteen koulutuksen ongelmia, korkeakoulupolitiikkaa, aikuiskoulutusta ja sivistyksen nostamista takaisin koulutuksen polttopisteeseen. Kirjoittajat ovat tunnettuja koulutuspolitiikan tutkijoita, virkamiehiä ja intressiryhmien koulutusasiantuntijoita. Kirjan nimi antaa odottaa kriittistä suhtautumista toteutettuun koulutuspolitiikkaan, eikä teos näitä odotuksia petäkään. Ongelma tietenkin on, että 90-luku on vasta jätetty taakse, ja aikaperspektiivi on kovin lyhyt funktionaalisten tai kausaalipäätelmien tekoon. Monien uudistusten tai päätösten toimeenpanokin on vielä kesken.

\section{Kirja on kriittisyydessään} kuitenkin hämmentävä lukukokemus. Kun sen julkaisija on tieteellinen laitos (Turun yliopiston kasvatustieteiden laitos), siltä odottaa analyyttista, evidenssiin pohjautuvaa kritiikkiä, tehtyjen päätösten positiivisten ja negatiivisten seuraamuksien tai odotettavien vaikutusten erittelyn kautta syntyneitä johtopäätöksiä. Nyt varsinkin teoksen toimittajat ovat valinneet shokeeraavien kielikuvien tien, vahvan “minä väitän” esitystavan ja päättäjien kykyä ja motiiveja kyseenalaistavan tien. Kritiikki sidotaan myyttisiin pahaa ilmaiseviin termeihin (globalisaatio, uusliberalismi, markkinavalta) pyrkimättä avaamaan niitä. Koulutuspolitiikan tie kadotukseen viitoitettiin siinä vaiheessa, kun kokoomuslaiset ministerit astuivat hallitusvastuuseen, ja tie jyrkkeni kokoomuslaisten opetusministerien kaudella. Kirjan kansikuvakin (jäävuoreen törmännyt Titanic uppoamassa) symboloi yliviritettyä kritiikkiä: koulutususkoiset ovat hukkumassa virheellisen navigoinnin seurauksena. Useassa artikkelissa pelätään erityisesti vapaan koulun valinnan ja muun "kaupallistumisen" ja "asiakaslähtöisyyden" seuraamuksia. Mielenkiintoista on, että Kiinan oppivelvolisuuskoulun oppilaiden vanhemmille ollaan GOSME-ohjelman puitteissa avaamassa mahdollisuus koulun valintaan. Mitenkähän odotettavissa oleva katastrofi tulevassa raportissa kuvitettaisiin?
Kysymys ei ole siitä, etteikö tällaista tekstiä tarvita. Se auttaa avaamaan silmiä, kyseenalaistamaan itsestäänselvyyksiä, analysoimaan vaihtoehtoja ja herättämään keskustelua. Itse nautin kirjasta ja sen esitystavasta. Ongelma onkin siinä, että tekstin ottaa tosissaan vain (poliittisesti) samanmieliset eivätkä ne, joiden toimia kritisoidaan, joiden olisi "tehtävä parannus”. Kirjan esityksistä vain vajaa puolet on perinteisiä . tieteellisesti koulutuspolitiikkaa kuvaavia tai analysoivia artikkeleita. Muut ovat pakinoita, esseitä ja mielipidekirjoituksia, jotka arvottavat kuvauskohteensa ennen niiden erittelyä. Kirjoittajat kritisoivat toteutettua politiikkaa poliittisen eivätkä tieteellisen argumentaation avulla. Valitut lähteet ovat usein mielipidekirjoituksia, tai vielä useammin, väitteiden tueksi ei esitetä mitään lähdeviitteitä. Arvoja ei voida "tieteellisesti" asettaa yksiselitteiseen tärkeys- tai paremmuusjärjestykseen. Preferenssilistat ovat itsessään arvovalintoja, mutta valituille arvoille antaa selkänojan faktat, joita vastaan on paljon vaikeampi väittää kuin mielipiteitä vastaan. Siksi olisi odottanut, että muun muassa sellaisille väitteille kuin "koulujen profiloituminen lisää oppilaiden eriarvoisuutta", "säästöt ovat merkittävästi aiheuttaneet oppimistulosten heikentymistä ja kiihdyttäneet koulujen lakkauttamista", "näytöt ja näyttötutkinnot ovat totaalisesti epäonnistunut uudistus”, "työssäoppimisjakson 
taustalla on ajatus palaamisesta tehtaan kouluun" tai "ammattikorkeakoulujen jatkotutkintojen käyttöönotosta riippuu, onko Suomi säilyttämässä dualistisen korkeakoulujärjestelmän", olisi esitetty tutkimusevidenssiä.

\section{Kaunopuheisuuden}

nimissä ei lukijaa pitäisi johtaa harhaan. Koulutuksen taloustiede ei ole niin yksinkertaista kuin kirjassa annetaan ymmärtää: "Jos työntekijän kouluttaminen maksaa puoli miljoonaa ja koulutus parantaa hänen tuottavuuttaan kymmenellä prosentilla, saadaan tulos, että kymmenen vuoden työskentely alan työtehtävissä maksaa koulutusinvestoinnin takaisin." (Eikö tarvita arviota diskonttokorosta, tuottavuuden määrittelytavasta, inhimillisen pääoman arvonalenemisesta, työvoiman kysynnästä ja tarjonnasta ja muista tuottoastetta modifioivista tekijöistä?) Tai “Jos ryhmän yhden vuoden koulutuskustannukset ovat 500000 markkaa, oppilaskohtaiseksi kustannukseksi tulee 50000 markkaa, jos ryhmässä on kymmenen oppilasta, mutta
25000 markkaa, jos ryhmässä on 20 oppilasta. (Yksikkökustannukseen vaikuttavat kiinteät ja muuttuvat kustannukset, laskeva tai nouseva mittakaavaetu, tekninen ja taloudellinen tehokkuus jne.).

\section{Kirja tuo esiin hyvin}

sen, miten vaikeaa on tehdä konsensus-Suomessa konsensuskoulutuspolitiikkaa. Artikkelit sisältävät teräviä havaintoja, oikeutettuja epäilyjä valitusta suunnasta ja myös vaihtoehtoja harjoitetulle politiikalle. Tosin vaihtoehdotkaan eivät ole ihan niin helposti toteutettavissa kuin yhdessä artikkelissa kuvataan: "Positiivinen diskriminaatio merkitsee sitä, että keneltäkään ei oteta pois vaan annetaan tarvitseville lisää." Diskriminaatiossa on aina kysymys voimavarojen (perustellusta) eriarvoisesta jakamisesta. Positiivinen diskriminaatiokin on mahdollista, jos niin poliittisesti tahdotaan. Viimeisten 50 vuoden kuluessa on eri maissa ollut monia laajoja positiivisen diskriminaation ohjelmia tarkoituksena parantaa vähäosaisten koulutussaavutuksia. (Nyt esimerkiksi
Englannissa.) Ohjelmia pitäisi vain jatkaa loputtomasti, koska koulu ei voi kompensoida muun yhteiskunnan eriarvoisuuksia. Meritokraattista yhteiskuntaa on vaikea kaataa. Koululla on jäljellä selektiofunktionsa, josta sen pitäisi päästä irti ennen kuin ihannekoulu saadaan syntymään. Tehokkuuden ja tasa-arvon ristiriita on pitkälti sovittamaton.

\section{Kirjan lukeminen antaa}

vahvan pohjan kritiikille ja sen jakamiselle, mutta tasapainoisen kuvan etsijälle on tarpeen lukea uudistetun koulutuslainsäädännön perusteluosat, sivistysvaliokunnan mietinnöt, 90-luvun komiteamietinnöt ja muut viralliset tekstit, joissa tehtyjä ratkaisuja perustellaan. Vasta sen jälkeen voi päätellä, ovatko 90-luvun poliitikot ja virkamiehet olleet täysin asiantuntemattomia, pahantahtoisia ja yksisilmäisiä. Kirja tarjoaa elämyksellisen lukumatkan, mutta on syytä kiinnittää turvavyö tiukasti ja tutkia myös vaihtoehtoisia ajoreittejä.

Reijo Raivola

\section{Yliopistollisia tutkimuksia}

- MERJA IKONEN-VARILA (2001) Koulutus ja työ valintana. Lastentarhaopettajaksi opiskelevien näkemyksiä alanvalinnasta ja työstä. Helsingin yliopisto - NINA SANTAVIRTA, EIJA AITTOLA, PAULA NISKANEN, IRMA PASANEN, KATRI TUOMINEN \& SVETLANA SOLOVIEVA (2001) Nyt riittää. Raportti peruskoulun ja lukion opettajien työympäristöstä, työtyytyväisyydestä ja työssä jaksamisesta, Helsingin yliopiston kasvatustieteen laitos

- LEILA PEHKONEN (2001) Täydestä sydämestä ja tarkoituksella. Projektityöskentelyn käsitteellistä viitekehystä jäljittämässä. Helsingin yliopisto, kasvatustiede

- HELENA ALLAHWERDI (2001) Kansainvälisyyskasvatuksen suosituksista maailmankansalaisen kypsyyskokeeseen, Suomen YK-Liitto kansainvälisyys kasvattajana 1970-2000. Helsingin yliopiston opettajankoulutuslaitos 